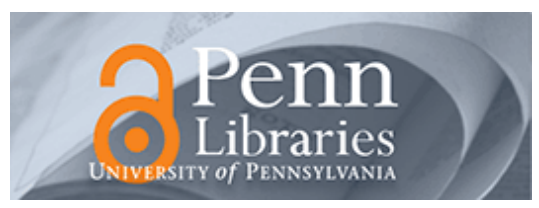

Manuscript Studies

Volume 4 | Issue 1

Article 8

2019

\title{
"Publishing" and Publics in a World Without Print: Vernacular Manuscripts in Early Modern India
}

Tyler Williams

University of Chicago

Follow this and additional works at: https://repository.upenn.edu/mss_sims

Part of the Asian History Commons, and the South and Southeast Asian Languages and Societies Commons

\section{Recommended Citation}

Williams, Tyler (2019) "'Publishing" and Publics in a World Without Print: Vernacular Manuscripts in Early Modern India," Manuscript Studies: Vol. 4 : Iss. 1 , Article 8.

Available at: https://repository.upenn.edu/mss_sims/vol4/iss1/8

This paper is posted at ScholarlyCommons. https://repository.upenn.edu/mss_sims/vol4/iss1/8

For more information, please contact repository@pobox.upenn.edu. 


\title{
"Publishing" and Publics in a World Without Print: Vernacular Manuscripts in Early Modern India
}

\begin{abstract}
How did one make a work 'public' in the world of pre-print South Asia? What are the textual and material aspects of manuscripts that alert us to their character as 'published' works intended to be circulated among members of an imagined readership removed from the author or scribe in space and time? Can such textual artifacts be systematically distinguished from copies intended primarily for the use of a single individual? This essay explores these questions in the context of literary and religious works and their copies produced in South Asia during the fourteenth through eighteenth centuries in the vernacular language known variously as Hindi, Urdu, Hindavi, or Hindustani. Comparing paratextual material like colophons, opening formulae, rubrics, and marginal inscriptions across different literary genres and across different reader communities as well as comparing material aspects of different types of manuscripts-e.g. bound and unbound, illustrated and unillustrated, notebooks and liturgical manuals, etc. - reveals patterns in the way that authors and scribes signaled the public character of a finished textual artifact. Making such comparisons among large corpora of manuscripts and reading certain paratexts "against the grain" reveals the contours of various emergent reading 'publics' before the rapid expansion of print technology in the eighteenth century.
\end{abstract}

\section{Keywords}

Manuscript studies, India, South Asia, Hindi, Urdu, Sanskrit, Persian, Vernacularization, Literature, Early modern, Multilingual 
Williams: "Publishing" and Publics in a World Without Print

\section{MANUSCRIPT STUDIES}

A Journal of the Schoenberg Institute for Manuscript Studies

VOLUME 4, NUMBER 1

(Spring 2019)

Manuscript Studies (ISSN 2381-5329) is published semiannually

by the University of Pennsylvania Press

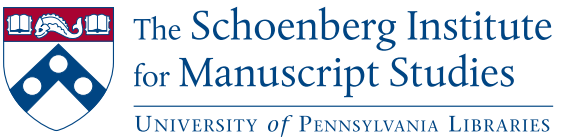




\section{MANUSCRIPT STUDIES}

VOLUME 4 , N UMBER 1

(Spring 2019)

ISSN 2381-5329

Copyright (C 2019 University of Pennsylvania Libraries

and University of Pennsylvania Press. All rights reserved.

Published by the University of Pennsylvania Press, 3905 Spruce Street, Philadelphia, PA 19104.

Printed in the U.S.A. on acid-free paper.

Manuscript Studies brings together scholarship from around the world and across disciplines related to the study of premodern manuscript books and documents, with a special emphasis on the role of digital technologies in advancing manuscript research. Articles for submission should be prepared according to the Chicago Manual of Style, $16^{\text {th }}$ edition, and follow the style guidelines found at http://mss.pennpress.org.

None of the contents of this journal may be reproduced without prior written consent of the University of Pennsylvania Press. Authorization to photocopy is granted by the University of Pennsylvania Press for libraries or other users registered with Copyright Clearance Center (CCC) Transaction Reporting Service, provided that all required fees are verified with CCC and paid directly to CCC, 222 Rosewood Drive, Danvers, MA 01923. This consent does not extend to other kinds of copying for general distribution, for advertising or promotional purposes, for creating new collective works, for database retrieval, or for resale.

\section{SUBSCRIPTION INFORMATION:}

Single issues: $\$ 30$

Print and online subscriptions: Individuals: $\$ 40$; Institutions: $\$ 92$; Full-time Students: $\$ 30$ International subscribers, please add $\$ 18$ per year for shipping.

Online-only subscriptions: Individuals: $\$ 32$; Institutions: $\$ 80$

Please direct all subscription orders, inquiries, requests for single issues, address changes, and other business communications to Penn Press Journals, 3905 Spruce Street, Philadelphia, PA 19104. Phone: 215-573-1295. Fax: 215-746-3636. Email: journals@pobox.upenn.edu. Prepayment is required. Orders may be charged to MasterCard, Visa, and American Express credit cards. Checks and money orders should be made payable to "University of Pennsylvania Press" and sent to the address printed directly above.

One-year subscriptions are valid January 1 through December 31. Subscriptions received after October 31 in any year become effective the following January 1. Subscribers joining midyear receive immediately copies of all issues of Manuscript Studies already in print for that year.

Postmaster: send address changes to Penn Press Journals, 3905 Spruce Street, Philadelphia, PA 19104.

Visit Manuscript Studies on the web at mss.pennpress.org. 


\section{MANUSCRIPT STUDIES}

A Journal of the Schoenberg Institute for Manuscript Studies

VOLUME 4, N U M B R 1

\section{Articles}

In the Age of Non-Mechanical Reproduction:

Manuscript Variation in Early-Modern South Asia

Arthur Dudney, Neeraja Poddar

Manuscript Variations of Dabistān-i Maz̄āhib

and Writing Histories of Religion in Mughal India

Sudev Sheth

Power Permutations in Early Hindi Manuscripts:

Who Asks the Questions and Who Gives the Answers,

Rāmānand or Kabīr?

Heide Paunels

The Strange Afterlife of Vidyāpati Țhākura (ca. 1350-1450

CE): Anthological Manuscripts, Linguistic Confusion, and Religious Appropriation

CHRistopher L. DiAmond

Prefatory Notes on Persian Idioms of Islamic Jurisprudence:

Reasoning and Procedures of Law-Making in Premodern

Islamicate India

Naveen Kanalu

Replication and Innovation in the Folk Narratives

of Telangana: Scroll Paintings of the Padmasali

Purana, 1625-2000

Anais Da Fonseca

Nectar or Arrow: Cases of Missense Textual Mutations in Early Kabïrian Padas

Zhang Minyu 
Manuscript Studies, Vol. 4 [2019], Iss. 1, Art. 8

iv | Journal for Manuscript Studies

"Publishing" and Publics in a World Without Print:

Vernacular Manuscripts in Early Modern India

Tyler Williams

\section{Reviews}

Kay Davenport. The Bar Books: Manuscripts Illuminated for Renaud de Bar, Bishop of Metz (1303-1316).

RICHARD A. LESON

Matti Peikola, Aleksi Mäkilähde, Hanna Salmi, Mari-Liisa

Varila, and Janne Skaffari, eds. Verbal and Visual

Communication in Early English Texts.

Lydia Yaitsky Kertz

Alpo Honkapohja. Alchemy, Medicine, and Commercial

Book Production: A Codicological and Linguistic Study

of the Voigts-Sloane Manuscript Group.

Winston BLACK

List of Manuscripts Cited 


\section{"Publishing" and Publics in a World Without Print: Vernacular Manuscripts in Early Modern India}

Tyler Williams

University of Chicago

I

N A SOCIETy LIKE that of early modern India that deliberately resisted the technology of print, how did one make a work "public"?1 Print publishing presupposes a public in which a printed text artifact will circulate but could that ever be the case for texts copied by hand and by a variety of actors in a myriad of social and institutional contexts? Even if we set aside the question of whether or not "publics" existed in pre-colonial South Asia we are still confronted by the question of whether and how the textual content and physical form of a text related to the imagined community of

1 The inhabitants of the subcontinent were aware of woodblock printing from at least the fourteenth century through materials printed in China and Tibet and brought to India. In the early modern period, the Mughals, the rulers of the Deccan Sultanates, and the rulers of coastal kingdoms where colonial traders and missionaries were active were definitely aware of printing in European languages through the printed books that these traders and missionaries brought with them and that they sometimes presented as gifts to Indian rulers. Nevertheless there appears to have been no printing activity within the subcontinent until the establishment of the Colegio de São Paulo Press in Goa in 1556. The reasons for this indifference toward printing have yet to be thoroughly explored. 
its putative audience. ${ }^{2}$ To put the question of this essay in another way: what did it mean to put a work "out into the world," to give it the material form of a manuscript with the intention that it would pass before the eyes (and its contents reach the ears) of strangers removed-potentially greatly removed-from the author or scribe in space and time? This essay explores this question in the context of manuscripts from early modern north India in the vernacular language variously called Hindi, Urdu, Hindustani, Hindavi, Brajbhasha, or simply bhāșā (spoken language).

This question is made all the more interesting and all the more important by the fact that many of the manuscripts that contemporary scholars now consult in their research were, at least ostensibly, not intended to travel all that far when they were created: many which have the form of commonplace books or song notebooks or that contain a single literary work were copied by or for a single owner, passing to another owner only upon the former's death or the dissolution of his wealth. Many other manuscripts, especially those of scholastic or religious works, were copied for the use of multiple persons, but these persons were often joined together by a single educational, monastic, or religious institution. Yet if we attune ourselves to subtle traces and details found within many of the aforementioned manuscripts we find that that they were indeed intended to reach a wider, imagined audience-an audience that, to borrow a phrase from Benedict Anderson in the context of nationalism, "is imagined because the members of even the smallest nation will never know most of their fellow-members, meet them, or even hear of them, yet in the minds of each lives the image of their communion," and that, to follow Brian Stock, are bound into "textual communities" in a way that is closely bound up

2 The question of whether anything resembling the modern notion of a "public sphere" existed in precolonial South Asia is a matter of debate. Interested readers are encouraged to consult Bernard Cohn, "The Indian Ecumene: An Indigenous Public Sphere," in The Indian Public Sphere: Readings in Media History, ed. Arvind Rajagopal (New Delhi: Oxford University Press, 2009), 49-64, and Christian Novetzke, "Bhakti and Its Public," International Journal of Hindu Studies 11, no. 3 (2007): 255-72. 
with literate practices that are somatic, social, and performative, as well as intellectual. ${ }^{3}$

There are a number of ways in which we can attune ourselves to the traces of circulation and performance present in these manuscripts and to the manner in which they reflect imagined audience communities. First, attention must be paid not only to the "primary" textual content of such manuscripts but also to paratextual features such as introductions, opening formulae, and colophons, as well as to visual and material features of manuscripts such as bindings, quality of paper, quality of illumination, penmanship, orthography, and so on. Looking closely at individual manuscripts and their respective histories is obviously necessary, but comparing large corpora of manuscripts to identify conventions and trends is equally important. On the one hand, we can sometimes observe how a particular work circulated in different types of manuscripts, thus reflecting different performance contexts and different audiences. On the other hand, in the cases in which we know something about the performance context of a work, putting that knowledge into conversation with observations about extant manuscripts of the work can illuminate previously unnoticed conventions and thus evidence of circulation. In a certain sense the methodological argument put forward here is simple: to pay attention to the histories of manuscripts after the moment of their production (or after their original context of use). Yet this can have profound-and sometimes counterintuitive-consequences for how we "read" textual artifacts from this place and time, in turn allowing us to see the emerging and emergent quality of manuscript books as a "commodity" in seventeenth- and eighteenth-century north India.

Despite the often remarkable accomplishments of manuscript surveys and conservation drives conducted in colonial and early post-colonial South Asia, almost no attention was given to creating a typology of premodern manuscripts beyond distinguishing the most basic of their material traits (birch bark, palm leaf, paper, etc.), or to classifying the various types of

3 Benedict Anderson, Imagined Communities: Reflections on the Origin and Spread of Nationalism (London: Verso, 2006), 6; Brian Stock, The Implications of Literacy: Written Language and Models of Interpretation in the Eleventh and Twelfth Centuries (Princeton, NJ: Princeton University Press, 1983). 
textual artifacts that were beginning to fill governmental and private archives. This is especially the case with the north Indian vernacular variously called Hindi, Urdu, Hindavi, Hindustani, Brajbhasha, or $b h \bar{a} s \bar{a}$, and to which I will refer using the conventional term "Hindi" for the sake of simplicity. Consequently, literary historiography of this vernacular has tended to "flatten" the archive by treating all textual artifacts as if they were the same in character, thus obscuring distinctions between, say, manuscripts created by individuals for their own use and manuscripts created by professional scribes for use by other individuals or even by groups. ${ }^{4}$ Yet those who commissioned, produced, and used these manuscripts clearly made distinctions between different types of "books." These distinctions are reflected both in the lexicon of written texts and in their material forms.

Giving a complete typology of these manuscripts is not possible here but a study of a few different forms and their variants will hopefully give a sense of the complexity and richness of this textual world. What follows is a description of two areas of vernacular textual production in the fourteenth through eighteenth centuries together with an analysis of the different "private" and "public" text artifacts in which they circulated. What can these manuscripts' material forms, contents, and histories tell us about the manner in which their composers and copyists imagined their respective audience communities?

\section{Stories and Storytellers}

The first example involves some of the earliest acknowledged "literary" works in Hindi, the so-called Sufi romances or prem-äkbyān (love narratives) of the fourteenth through seventeenth centuries, and the bound codices in which they most often circulated. Inaugurated by Maulana Daud's Candāyan in 1379, the genre adapts the Persian masnavī to Indic

4 This "flattening" was also the result of the philological and historiographical techniques of the time that privileged the discovery or reconstruction of ur-texts over the study of the processes of circulation and differentiation through which a text's versions multiplied-arguably one of the most interesting facets of South Asian textual culture. 
meters and themes with the narrative functioning simultaneously as an allegory of Sufi spiritual practice and as an object for refining affective regimes of connoisseurship and love. ${ }^{5}$ Consequently these romances were performed and enjoyed at royal courts, in Sufi hospices, and even in the homes of relatively affluent (but decidedly not "elite") individuals who had neither Sufi nor royal connections. Though the earliest extant copies of these works were created decades to centuries after the texts' initial composition, internal evidence in the works themselves along with evidence from existing copies and anecdotal material from contemporary sources suggests that these versified romances circulated in written form from the moment of their creation and quickly became canvases for the illustrative and book arts of the subcontinent and the broader Persianate world. ${ }^{6}$ Almost none of the extant copies include their original bindings; nevertheless, there is sufficient evidence to suggest that the majority followed a single format in which they were inscribed in portrait orientation and bound as codices with text on the right-hand folio and corresponding illustration (when present) on the facing, left-hand folio (fig. 1). ${ }^{7}$

5 On the Indic Sufi romance genre see Aditya Behl, Love's Subtle Magic: An Indian Islamic Literary Tradition, 1379-1545 (New York: Oxford University Press, 2012).

6 Relatively little scholarly work has been done on Persianate manuscripts from the Sultanate period in north India, perhaps a result of the relatively small size of this archive. Éloïse Brac de la Perrière has recently published two extremely illuminating works on this corpus that are pertinent to the study of vernacular manuscripts as well: see L'art du livre dans l'Inde des sultanats (Paris: PUPS, 2008); "The Art of the Book in India Under the Sultanates," in After Timur Left: Culture and Circulation in Fifteenth-Century North India, ed. Francesca Orsini and Samira Sheikh (New Delhi: Oxford University Press, 2014), 301-38. On the illustrative programs of vernacular Sufi romances, see Qamar Adamjee, Strategies for Visual Narration in the Illustrated 'Chandayan' Manuscripts, Ph.D. dissertation, New York University, 2011.

7 Variations on this form begin to appear in the eighteenth century. A good example is the 1741 copy of the Madhumālatì (1545) of Manjhan in the University of Pennsylvania collection (UPenn MS Indic 28): copied in a Kaithi-influenced Nagari script, its wide, loose folios and red and black margin lines follow the conventions of the pothi-type manuscripts described below. Nevertheless, there is a striking general consistency in the format and impagination conventions of the manuscripts of these romances, with later copies in the Nagari and Kaithi scripts imitating earlier and contemporary copies in the Perso-Arabic script. 

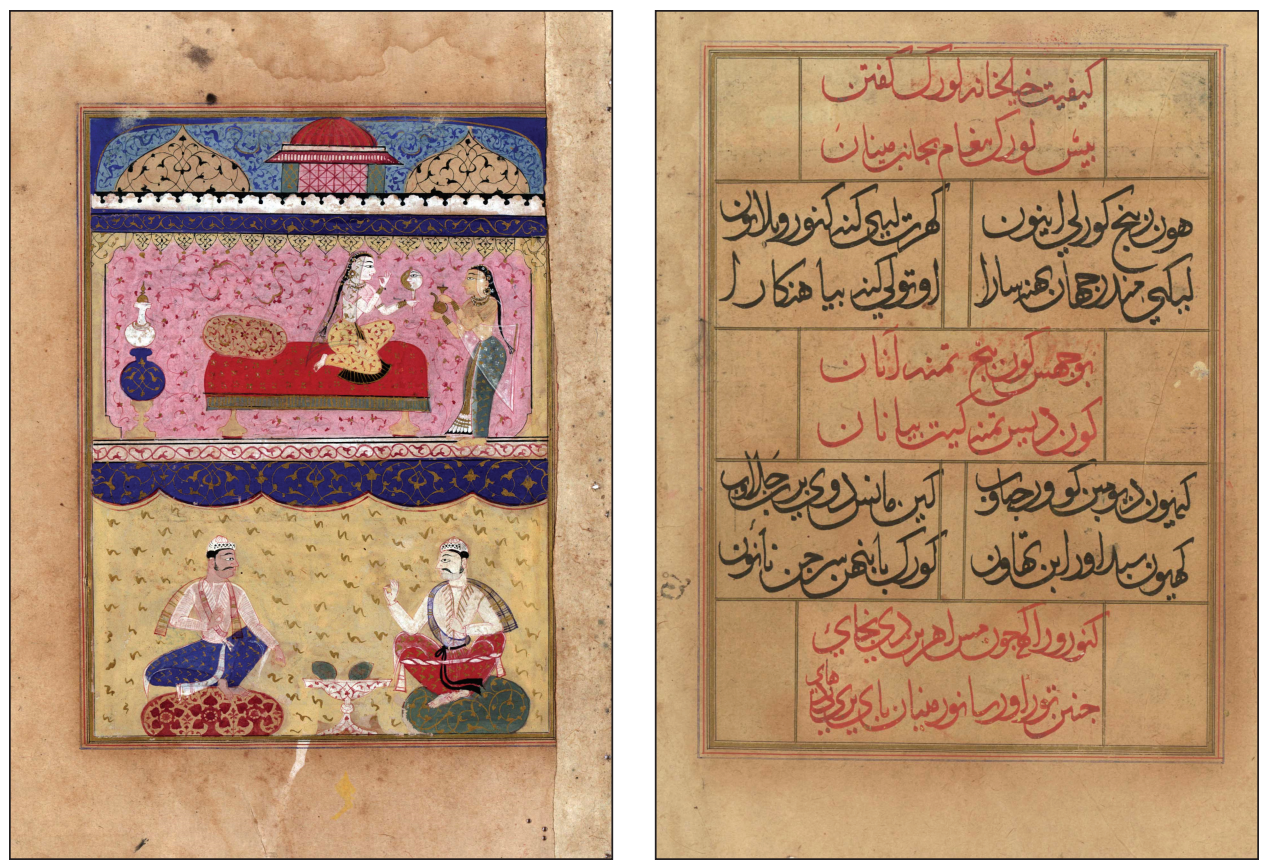

FIGURE 1. The Candāyan (1379) of Maulana Daud (listed as the Tale of Laurik-Chanda in the museum catalog). Chatrapati Shivaji Maharaj Vastu Sangrahalaya, acc. no. 51.1. Fols. 42 (a) and 43 (b), showing facing text and illustration.

These manuscripts, following as they do the model of the Arabic and Persian kitäb (codex), often include a colophon inscribed in a wedge shape on the final folio. Such colophons may include any of the following details: the name and background of the copyist; the name, social status, and native place of the commissioning patron; the time and place of copying; and the cost at which the copy was produced. ${ }^{8}$ Let us consider an example taken from a lesser-known but fascinating work of the genre, the Nal-Däman (1657) of Surdas. ${ }^{9}$ The only known copy of the work is held by the Chatrapati

8 Notations by subsequent owners regarding when and where the manuscript was obtained or purchased are also found; for the purposes of this study, we are concerned only with the colophon inscribed at the time of the manuscript's "original" production.

9 As Motichand makes clear in his essay (the only scholarly article on the manuscript of which I am aware), this seventeenth-century Surdas of Lucknow is not to be confused with 
Shivaji Maharaj Vastu Sangrahalaya in Mumbai (acc. no. 22.3229). The colophon appears on the final folio of the manuscript, inscribed in a wedge shape between fields and bounding lines painted in gold, red, and blue (fig. 2). The scribe, Babullah, writes the following in Persian-not Hindibut occasionally, and suggestively, slips back into the vernacular:

Thus was completed this passion-igniting, delight-increasing, paindispelling, elegant mine of lovers, this fountain of truth and allegory, on the afternoon of Monday the fourth at the request of that master of discretion, that lord of taste, that giver of peace, man of good fortune, of courage and of praiseworthy nature, marked like a king, the Rustam of his day, the Hatim of the age, seated on the throne, liberal and generous, kind and compassionate, Miyan Diler Khan, peace be upon him, and inscribed by low and unworthy supplicant Babullah, son of Sayid Muhammad Zahad Husan alHusayni al-Bukhari al-Najafi, in the year 1110 Hijri [1698 CE], in the twenty-third year of the rule of Emperor Mahiuddin Aurangzeb 'Alamgir the courageous-may his lands and reign increase.

Let us ask a seemingly naïve question: why would one bother to include this information in a colophon if the copy was intended to be used solely by the person who commissioned it (in this case, Diler Khan)? ${ }^{10}$ I say naïve, because those familiar with such manuscripts or with the literary world of this time and place would be able to give at least several potential reasons: for example, such a colophon "performs" the moment of inscription and consequently marks the prestige of the individual who commissioned it; in manuscript culture, a copy of a work had to be borrowed or lent in order for

the famous sixteenth-century composer of the Sūrsāgar. See Dr. Moti Chand, "Kavī Sūradās Krọt Nal-Dāman Kāvya,” Nāgarīpracāriṇī Patrikā 19, no. 2 (1948): 121-38. I thank Thibaut d'Hubert for bringing my attention to this work and for his assistance in reading the colophon.

10 Those familiar with Mughal history will recognize Diler Khan as the name of a prominent Pashtun general and noble at the Mughal emperor Aurangzeb's court; despite several details that suggest that this may be the same Diler Khan, the date of the manuscript seems to contradict this: its date of copying is six years after the general's death. 
Manuscript Studies, Vol. 4 [2019], Iss. 1, Art. 8

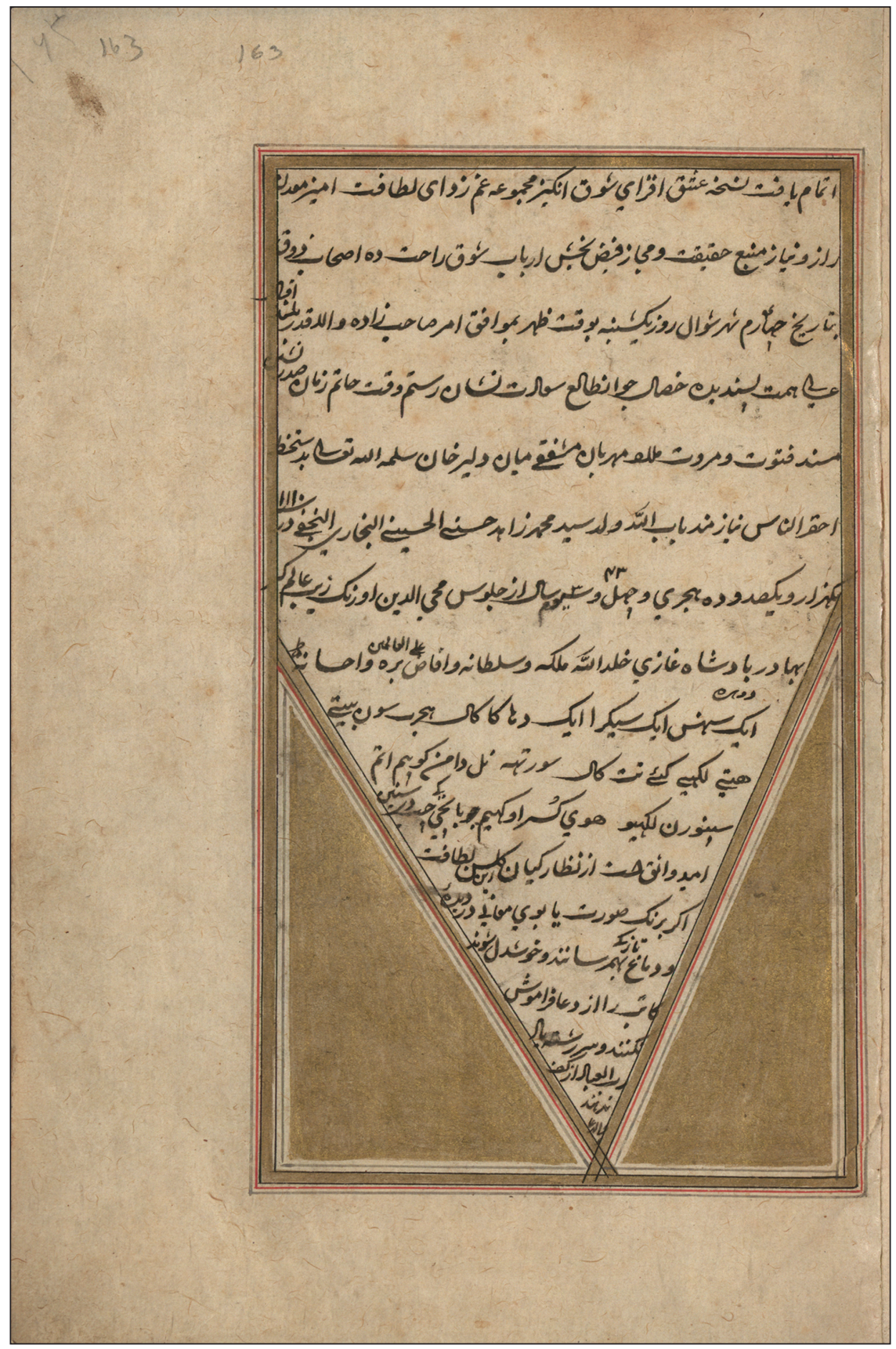

FIgURE 2. The Nal-Dāman of Surdas. Chatrapati Shivaji Maharaj Vastu Sangrahalaya. Acc. no. 22.3229. Fol. 163. 
a new copy to be produced, therefore the colophon was (at least in theory) a safeguard that the manuscript would be returned; books were passed down through genealogical and monastic "lineages" as heirlooms and so colophons served to help mark such social bonds and the transmission of spiritual and scholarly authority. There are many more potential reasons of both practical and symbolic natures, some of which I discuss further below. What I wish to emphasize here is that all of these potential functions of the colophon have a social dimension and relate to contexts that are subsequent to the manuscript's initial use or context of ownership. Yet when we as modern scholars give attention to such colophons we are often inclined to read them primarily as documents or traces of the scribe's or patron's identity, historical context, and so on, forgetting to ask the simple question: for whose eyes were these notes actually intended? Keeping this question in mind leads to an ostensibly paradoxical but exciting realization: every colophon is simultaneously a mark of the presence of the initial scribe (or user) and the presence of that unknown, anonymous reader of the future. Who would these later readers have been?

Information about the performance contexts and circulation patterns of vernacular manuscripts in pre-colonial north India is not in great supply; nevertheless anecdotal evidence from contemporary sources and practices related to codices of Persian and Arabic works give us some material with which to work. For example, the Jain merchant Banarasidas (1586-1643) relates that he was able to obtain copies of Qutaban's Mirgāvatī (composed 1503) and Manjhan's Madbumālatī (1545) in Agra, from which he recited to a group of enthusiastic and appreciative friends. ${ }^{11}$ How and from where did he obtain these manuscripts? It is possible that he purchased them from one of the book bazaars for which Agra (as well as Delhi and Lahore) was known at the time. ${ }^{12}$ Given his penniless state at the time of the events

11 Banarasidas, Half a Tale: A Study in the Interrelationship Between Autobiography and History: The Ardhakathanaka, ed. Mukund Lath (Jaipur: Rajasthan Prakrit Bharati Sansthan, 1981), vv. 335-36.

12 Muzaffar Alam and Sanjay Subrahmanyam, "The Making of a Munshi," in Writing the Mughal World: Studies on Culture and Politics (New York: Columbia University Press, 2012), 317. 
described, it is likely that Banarasidas borrowed them. ${ }^{13}$ Either scenario establishes that copies of these works were circulating at the time and that even a failed and impoverished merchant could get his hands on some.

Copies of these same works made their way into the hands of Persianliterate Sufis like Muhammad Shakir Amrohavi (who made his own copy of the Padmāvat in 1674 and added an interlinear, original Persian translation) and Mughal nobility like the Hindu Persian poet from Punjab, Anandram "Mukhlis," who composed a Persian translation of the Padmāvat in $1739 .{ }^{14}$ Among Mughal elites, manuscripts were a commodity of substantial economic and social significance. From the time of the Mughal emperor Akbar (r. 1556-1605), detailed appraisal of the value of manuscripts in an individual's library was a routine part of auditing an individual's wealth (and this practice extended all the way up to the emperor himself). Libraries of the deceased or the insolvent were sold or auctioned; used copies of manuscripts were to be found in the aforementioned book bazaars. Manuscripts were also an important form of "loot": it was common practice for a victorious monarch or his military representative to confiscate the library of the enemy and distribute its contents among the nobles who participated in the campaign.

The frequency and variety of modes through which manuscripts thus changed hands give us reason to reflect on why copyists like Babulla inscribed colophons and information with which to understand why such copyists included the information that they did. A connoisseur of vernacular poetry like Diler Khan and a talented calligrapher like Babulla would have been well aware of the market for the luxury item that they were creating and of the profile and tastes of potential future owners or readers of the manuscript. The very fact that the colophon was inscribed in Persian tells us that

13 Banarasidas, Half a Tale, vv. 335-36. The peculiar syntax and placement of the break between these two verses leaves open the possibility that $u d h \bar{a} r$ can be read for $u d \bar{a} r$ in Lath's text, meaning that Banarasidas took the manuscripts "on loan" from someone else. This would make sense given Banarasidas's state of penury at the time, which he describes in great detail.

14 Shantanu Phukan, “Through Throats Where Many Rivers Meet': The Ecology of Hindi in the World of Persian," Indian Economic and Social History Review 38, no. 33 (2001): 33-58. 
it was intended for the eyes of Persophone and culturally Persianized Mughal elites. Producing such a manuscript was a significant financial investment and it is reasonable to assume that a man like Diler Khan would have wanted to see that investment reflected in the exchange value of the finished product. In this context, what does such a colophon "do"? What is its purpose? One can argue that a colophon is a convention, but conventions also perform social or informational functions. In this case the colophon indexes the wealth that the manuscript represents to the individual-and would have continued to do so even after the manuscript was sold, exchanged, given as a gift, captured, and so on. In this sense the colophon as an index of wealth is memorial.

Yet is it also possible to understand such a colophon as increasing the value of the manuscript? Subsequent owners of such manuscripts did not typically remove such colophons but rather added their own marks of ownership in the form of seals and inscriptions. A subsequent owner of Diler Khan's copy of the Nal-Däman made such radical changes as having illustrations from another manuscript pasted into the Nal-Dāman, even covering over portions of the text, but left the colophon untouched. ${ }^{15}$ The tendency to retain original colophons along with the frequent presence of illumination in and around colophons (again adding value) suggests that the colophon played a role in establishing the value of the manuscript (reckoned in economic, social, or political terms). The notation of the identity of the original commissioner or owner could serve as a guarantee of artisanal quality: for example, South Asianists will recall the reputation of the manuscript atelier of Abdul Rahim Khan-i Khanan (1556-1627), famous for its exquisite productions of Persian classics. ${ }^{16}$ The name of the original patron could also serve as a token of prestige: to acquire a volume formerly possessed

15 The book historian Ulrike Stark has suggested that this somewhat anomalous case may have a more modern provenance: an individual trying to increase the value of the manuscript before selling it to a museum or collector. Detailed material, visual, and textual analysis of the manuscript will be required before we can have any idea of the possible date or source of the later illustrations.

16 John Seyller, Workshop and Patron in Mughal India: The Freer Rāmāyana and Other Illustrated Manuscripts of 'Abd Al-Rabìm (Washington, DC: Artibus Asiae, 1999). 
by a person of note-either through military conquest or through purchase-was to appropriate some of the prestige or aura of that individual. ${ }^{17}$ In the case of this manuscript, the lengthy list of honorifics-substantial but by no means excessive for the time-would have increased this prestige and aura. At the same time, the calligrapher's "signature" could have acted both as a stamp of artisanal quality and as a visiting card of sorts: anyone who encountered the manuscript would know who to contact for the production of manuscripts of similar quality.

In all of these cases, the inscription of the colophon, though marking private ownership or use by a single individual, simultaneously addresses an imagined community of collectors, dealers, and connoisseurs. Although the exact identity of these future "readers" could not be known, their tastes and social identities and contexts could be predicted with reasonable accuracy. That they included Jain merchants like Banarasidas, Sufis like Amrohavi, and Mughal literati like Mukhlis reveals the heterogeneous, public-like nature of this community and thus the published-like nature of the manuscripts.

\section{Songs and Scholarship of Saints}

Distinct from but overlapping with the world of the Sufi romances was the world of bhakti (devotional) singers, saints, and scholars. The "saint-poets" of this religious and literary tradition used much the same linguistic register

17 The transfer of an individual's aura or power (variously imagined as barakāt, śakti, $d u^{\prime} \bar{a}$, etc.) through materials with which he or she has had contact has been noted in the case of Mughal emperors, and there is evidence suggesting that this belief functioned more generally in early modern north India. See Bernard Cohn, Colonialism and Its Forms of Knowledge: The British in India (Princeton, NJ: Princeton University Press, 1996), 19; Balkrishan Shivram, "From Court Dress to the Symbol of Authority: Robing and 'Robes of Honour' in PreColonial India," Studies in Humanities and Social Sciences 13, no. 2 (2015): 1-28. Although books have not been studied as conduits for such power, the practice of noting when a manuscript passed "under the gaze" (dar nazar) of the emperor strongly suggests that they were receptive mediums for his power. On manuscripts as receptacles of aura in a religious context, see below. 
and drew upon a similar set of religious concepts as the authors of the Sufi romances but their compositions were largely (though not exclusively) in the form of hymns (bhajan/kirtan) or epigrammatic couplets (dob $\bar{a} / s \bar{a} k b \bar{\imath})$. The earliest stratum of the manuscript archive for this tradition (the earliest manuscripts date to the late sixteenth century though the poetry dates to at least the fifteenth) already reflects a distinction between manuscripts intended for personal use and those intended for a wider audience. This distinction becomes even clearer when we compare manuscripts containing the songs of the saints with those containing the scholastic compositions of their later followers.

The manuscript libraries and archives of north India abound with notebooks and songbooks, manuscripts that were clearly copied by an individual for his personal use. ${ }^{18}$ These were typically made by stacking and folding folios, then sewing them along the fold into a cloth binding (in a manner largely identical to the babis or account books of the time). Consequently, the more folios were added to the manuscript, the more rounded its shape became; this is possibly the reason that these wide-format manuscripts are generally referred to as gut $k \bar{a}$ (from Sanskrit gutik $\bar{a}$ [ball]), but it should be noted that this term is sometimes used to refer to other types of manuscripts as well. Although these notebooks primarily contain hymns composed by the bhakti saints, they also often contain other material such as records of business transactions, astrological charts, mantras, magic formulas, travelogues, and even recipes. The wide variety of this material draws our attention first to the diversity of individuals who used such notebooksincluding monks, merchants, and mendicants - and second to the character of these manuscripts as personal notebooks. This impression is strengthened by the general absence of paratextual material like verse numbers or subject headings that would help one to find material within the manuscript and by

18 I use the possessive pronoun "his" because, although women were central to the development of the religious communities under consideration here, we do not yet have any evidence of their participation in the scribal activities of these sects. It should be noted that the role of women in shaping devotional practices and sectarian structures within the socalled bhakti movement remains an important aspect of this history that has yet to receive sufficient attention. 
the relatively relaxed character of penmanship. To put it another way, the amount of work that a modern researcher has to put in to read the messy and idiosyncratic hands and find specific material within a great mass of undifferentiated text should tell us that the scribe was most likely not writing for the eyes of anyone else and that the manuscript functioned like an aide-memoire, a prosthetic of memory that would have been of use to someone who already knew its contents and their respective locations.

Hagiographical and other documentary evidence suggests that these notebooks were used to aid singers in communal worship: in fact, communal singing of hymns appears to be one of the primary, if not the primary, liturgical mode through which bbakti religiosity was spread and bbakti religious communities were consolidated in the early modern period. ${ }^{19}$ Although we must be careful not to extrapolate too far from modern practices, the antiphonal singing practices documented during the early colonial period probably had antecedents in the pre-colonial period of the fifteenth through eighteenth centuries, and in this context these songbooks would likely have served those who led such singing. ${ }^{20}$ The rich diversity of saint poets whose hymns are collected together in these manuscripts and the variety of organizational principles (if any) for the material that can be inferred from studying the content closely suggest that these manuscripts reflect the personal preferences and interests of their users rather than any doctrinal or sectarian logic. (Thus one finds hymns by poets like Kabir and Tulsidas, poets whose respective theologies and aesthetics are characterized

19 For example, communal singing features prominently in the hagiographies of the Dadu Panth, Niranjani Sampraday, and Vallabha Sampraday. See Jangopal, Dādū Janm Lìlā, ed. Winand Callewaert, as The Hindi Biography of Dadu Dayal (Delhi: Motilal Banarsidass, 1988);

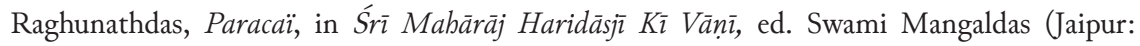
Nikhil Bharatiya Niranjani Mahasabha, 1962); Gokulnath, Caurāsī Vaișnavan Kī Vārtā, ed. Dwarkadas Parikh (Mathura: Dwarkadas Parikh, 1960); and Nabhadas, Bhaktamāl, with Commentary of Priyadas, ed. Rupkala (Lucknow: Tejkumar Press, 1914).

20 On the use of manuscript notebooks in devotional singing in the close and closely related region of Maharashtra, see Christian Novetzke, Religion and Public Memory: A Cultural History of Saint Namdev in India (New York: Columbia University Press, 2008). On the use of handwritten notebooks in contemporary bhakti musical performance, see Linda Hess, Bodies of Song: Kabir Oral Traditions and Performative Worlds in North India (New Delhi: Oxford University Press, 2015), 72-90. 
as being mutually opposed in most modern scholarship, sitting cheek-byjowl in many early modern notebooks.) This is particularly the case for such notebooks dating to the early seventeenth century-the earliest period for which we have extant material. ${ }^{21}$

Contemporary with these songbooks, we also find manuscripts that contain many of the same hymns but that inscribe and present this material in a manner that is distinctly public in that it is addressed to the eyes, ears, and imaginations of a much broader community. These long-format, bound codices do not have a technical name, but are generally referred to as vān̄is ("voice," specifically the voice of the saint or saints whose compositions are contained therein). They contain primarily hymns but often also the aforementioned epigrams (dohāas $\bar{a} k b \bar{\imath})$ of the saints as well as sometimes hagiographic or scholastic material. In content as well as form these appear to be proper liturgical equipment in that they supply the tools necessary for both teaching/sermonizing and communal singing: aphoristic couplets that occasion longer sermonizing (pravacan), edifying tales of the saints' lives, and of course the hymns that were the focal center of communal worship, all within a portable and well-stitched codex with a heavy protective cover. (Monika Horstmann has consequently called them the equivalent of a vademecum. $)^{22}$ The hagiographic texts of at least one of these religious communities, the Dadu Panth of Rajasthan, reflect a clear intentionality in this regard: the Dādū Janm Lìlā (1620), Bhaktmāl (1660) of Raghavdas, and Sant Gun Sägar (1604?) together relate how the songs and sayings of the sect's founder, Dadu Dayal, were scrupulously recorded, collated, and anthologized by his disciples, and copies were then distributed among the monks of the sect for use in their teaching as they were sent out to proselytize. In fact, the earliest copies of such vānī manuscripts to which we currently have access and which date to the first quarter of the seventeenth

21 Tyler Williams, Bhakti Kāvya Mè̇ Nirgun-Sagun Vibhājan Kā Aitihāsik Adhyayan, M.Phil. dissertation, Jawaharlal Nehru University, 2007.

22 Monika Horstmann, "Dādūpanthi Anthologies of the Eighteenth and Nineteenth Centuries," in Bhakti in Current Research: Proceedings of the Ninth International Conference on Early Devotional Literature in New Indo-Aryan Languages, Heidelberg, 23-26 July 2003, ed. Monika Horstmann (New Delhi: Manohar, 2006), 164-71. 
century contain the compositions of five saints (including Dadu) revered in both the Dadu Panth and the Niranjani Sampraday, and have thus come to be called pañ $-v \bar{a} n \bar{\imath}$ ("the five voices"). Around the same time, another type of anthology was created in the same sect, called the sarvāingi (lit. 'all parts'); as the name implies, this voluminous type of anthology was meant to include hymns and saying from all the saints, past and present, recognized by the tradition.

The sectarian imprimatur on such manuscripts is discernible in their paratexts, organizational schemes, and visual presentation. All begin with an invocation to God and/or the founding saint of the respective tradition (Dadu, Haridas Niranjani, Kabir, etc.); importantly, this invocation is either in Sanskrit or a type of pseudo-Sanskrit produced by appending Sanskrit case endings to vernacular stems, or otherwise combining conventional formulae taken from Sanskrit, despite the fact that the liturgical content of the manuscript is in the vernacular. For example, the early eighteenthcentury saint vān̄i kept at the Sanga Kua Niranjani temple in Didvana, Rajasthan-about which I will say more below-begins with the following invocation in red ink (commonly used for rubrics, in contrast to the black ink used for texts): śrī niranjanāya namah. śrī ganāddipatbyaya namaḥ. śrī sakala santamabāpuruṣaya nama. atha gusāimī jī śri śrī turasīdāsa jī kau krta likbyate. (Obeisance to the great Niranjan. Obeisance to the great Leader of the Ganas [Ganesh]. Obeisance to all the great saints. Thus are written the compositions of the great, great Gosvami Tursidas. $)^{23}$ To those familiar with manuscripts in Indic languages, such opening invocations are so ubiquitous as to seem unremarkable; however, in this particular context, I want to emphasize that their presence marks these manuscripts out as distinct from the aide-memoires discussed above. Their closing formulae also mark them as objects that are more sacred than everyday notebooks; let us take

23 Those familiar with Sanskrit or Hindi will note the grammatical inconsistencies and mixing of Sanskrit inflections with the analytic syntax of Hindi, not to mention the vernacular morphology applied to Sanskrit terms. What is not apparent from this transcription is the manner in which the orthographic rules of the vernacular have also been applied to the Sanskrit, with, for example, the same glyph being used for both the retroflex sibilant ș and velar kha. 
for example the case of the sarvāingi of Gopaldas of the Dadu Panth. First, the anthology itself carries a closing colophon in which Gopaldas gives his guru-disciple lineage (he is the grand-disciple of the founder Dadu himself), the location at which he assembled the anthology (Sambhar, in the feudatory lands ruled by Mirza Julkaraya), the date of completion (the day of the full moon in the month of phalgun, Vikram 1684, i.e., 20 March 1628), his age at the time, and the conditions under which he was moved to compile the anthology:

Thus ends the book [pothī] named the Great Sarvāngī, the wishfulfilling jewel. ... When [I], Gopaldas, was thirty-seven, I assembled all of this. [Dadu's?] sister gave the order: Guru Govind [God] has given this gift, this book [pustak] to be recited. [From it] the ignorant will become wise, and error and karma will be removed. The difficulties of all beings will be solved by the knowledge of the Good Ones [sādhau] that I have assembled in one place. One should understand this to be from the mouth of the Guru, the voice of the True Ones [sati pūrișāim]. ${ }^{24}$

Again, the inclusion of a phalaśruti ("fruit of listening," an explanation of the benefit to be gained by listening to or reciting a text) will not seem unfamiliar to specialists of South Asian texts, but its inclusion bere is remarkable, in an anthology of vernacular hymns and aphorisms. It "packages" the diverse contents of the anthology and guarantees their soteriological efficacy. And although, on the one hand, Gopaldas invokes the divine origins of the textual content, describing it as a gift from Guru Govind who is beyond time and the phenomenal world; on the other hand, he locates himself in historical time-in a specific location, in a specific pargana (district) of the Mughal Empire, at a specific time. What unites the timeless and the historical here are the sati pürișa, the saints, who act as mediums between the divine and the quotidian. It is also notable that Gopaldas twice

24 Gopaldas, The Sarvågī of Gopāldās: A 17th Century Anthology of Bhakti Literature, ed. Winand Callewaert (New Delhi: Manohar, 1993), 520. 
refers to his anthology using terms that reference the materiality of the text: pustak, a term for a written text adopted from Sanskrit, and potbī, a phonologically altered form of the same term that came into Hindi via Prakrit and Middle Indo-Aryan languages. Such self-conscious references to the materiality of the text are wholly absent from the hymns and aphorisms that make up the bulk of saint literature and are also rare in the more scholastic writings of the bbakti corpus. ${ }^{25}$

Gopaldas's colophon is reproduced in copies of the anthology, augmented by the colophons of the scribes who made those copies. Like Gopaldas, they report their name, guru-disciple lineage, location, and the date on which they completed the manuscript. These colophons effectively constitute a record of the text's transmission and guarantee of its accuracy in a manner somewhat analogous to the "blockchain" technology of modern-day crypto currencies (albeit without the cryptography). As I have argued elsewhere, the inclusion of guru-disciple lineages in colophons (often reaching back several generations to the founder of the sect) take on an added significance in light of the epistemological and pedagogical beliefs of the period; according to beliefs prevalent in both Hindu and Muslim religious scholarship, written texts required the mediation of a qualified teacher to be transmitted properly. ${ }^{26}$ Even if many scribes approached their work mechanically during this period (and we have plenty of poor-quality manuscripts attesting to this fact), the transmission of religious scholarly and liturgical books was a context in which accurate transmission by an intellectually qualified scribe was deemed essential and scribes appear to have been aware of this expectation (even

25 The most common term for a textual composition is racana , which could be translated as "creation" or "composition." Even hyper-literate poets such as Tulsidas (fl. 1600) and Nandadas (fl. mid-sixteenth century) have little to say about the materiality of their works or of writing in general. (The only exception being Tulsidas's metaphorical reference to writing in the Rāmcaritmānas, "kabita bibeka eka nahim more / satya kahaüm likhi kāgada kore" (I know nothing of poetic mores; I speak the truth, writing upon blank papers).

26 "Notes of Exchange: Scribal Practices and Vernacular Religious Scholarship in Early Modern North India," Manuscript Studies: A Journal of the Schoenberg Institute for Manuscript Studies 3, no. 2 (2018): 265-301. 
if they did not always meet it in actual practice), as reflected in their rehearsal of their monastic credentials. ${ }^{27}$

Perhaps the most striking features of $v \bar{a} n \bar{\imath}$ manuscripts are the quality and detail of their navigational apparatuses. All hymns are numbered and organized according to raga, facilitating use in musical performance; all aphorisms are numbered and organized according to theme (ang [limb]), facilitating use in sermonizing and pedagogical contexts. Furthermore, most manuscripts of this type include a comprehensive table of contents with section titles and folio numbers - a major innovation at the time. As mentioned earlier, rubrics_-including section headings, verse numbers, and raga notations-are inscribed in red ink, making them stand out visually on the page.

Finally, vān̄ manuscripts were clearly made to be visually impressive: they feature high-quality calligraphy, decorative uses of ink, and decorative embellishments like floral designs and margin lines. The sectarian vāñ of the Niranjani Sampraday held by the Rajasthan Oriental Research Institute at its Jaipur branch (MS 2165), with its patterned use of ink for the text, is a particularly striking example of the time, energy, and money that was invested in making these codices sufficiently impressive for communal worship (fig. 3). So even though the colophon of a particular manuscript will often report that it was copied by a monk for the use of his guru or another religious leader (again including a rehearsal of the scribe's entire gurudisciple lineage), these manuscripts appear to have been intended for everyone's eyes, at least everyone present in communal worship. In this sense, these were public objects. They did not "circulate" in the sense that they were silently "read" in private contexts by different individuals; rather, their

27 And thus the complaint of Sain, the copyist of an 1863 manuscript of Anandram's Paramānand Prabodh, who ends his colophon with the following couplets: "Chest, butt, neck, eyes, and mouth / The wise endure bodily pain / This is written with great difficulty / [But] everyone thinks it's easy. / The jeweler [endures] great difficulties / With [his] face and eyes bent down / Sain strung this jewel / [By] writing this manuscript." Rajasthan Oriental Research Institute, MS 16699, folio unnumbered (but corresponds to Folio 233 recto according to the numbering present in earlier folios). I thank Akshara R. Parmeswaran for reading this manuscript with me and for her insights into its relationship with the text of the Bhagavadgita $\bar{a}$, of which it is a commentary. 
Manuscript Studies, Vol. 4 [2019], Iss. 1, Art. 8

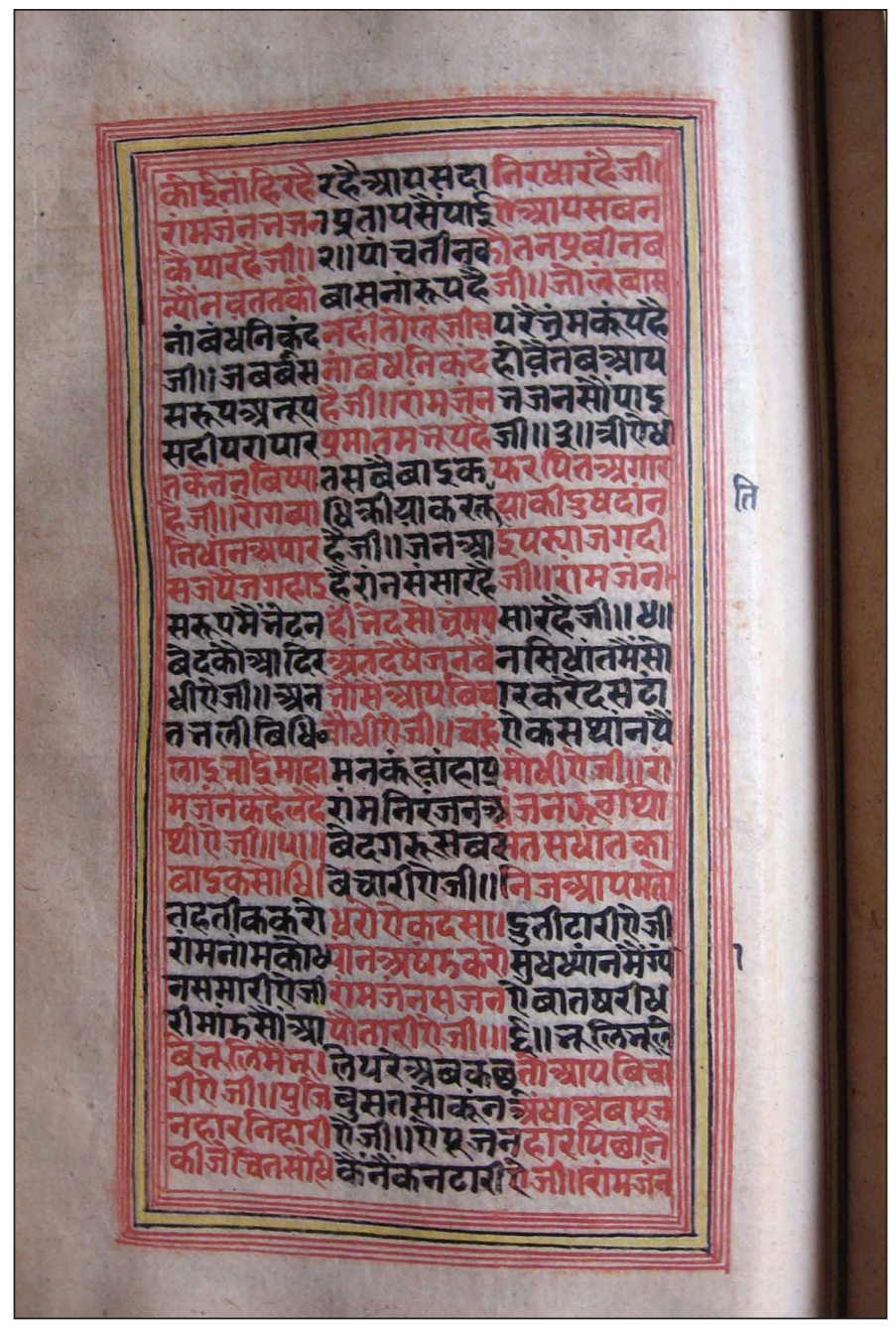

FIGURE 3. Vānii of Tursidas, etc. Rajasthan Oriental Research Institute, Jaipur. MS 2165. Fol. 3.

publicness derived from their visual presence in the context of communal worship and from the manner in which they were "made to speak" (vacayati in Sanskrit, baimc- in Hindi) by qualified religious teachers. After all, as their name makes clear, these manuscripts held "the voice" (vānin) of the Guru, a voice to which all had equal access according to the social ideologies 
and soteriologies of the religious communities considered here. ${ }^{28}$ And at least in the case of the Niranjani Sampraday community, when a particularly charismatic religious leader died, his copy of the vānn was installed in his samādbi (monument) or in a temple (as in the case of the Sanga Kua manuscript discussed above) as an object of worship. ${ }^{29}$ Although scholars have long been aware of the centrality of the material object of the Guru Granth Sabib, the scripture of the Sikhs, in public ritual, similar phenomena in Hindu communities like the Dadu Panth, Niranjani Sampraday, Ramsnehi Sampraday, and (I would argue) the Vallabha Sampraday have yet to receive comment or analysis.

\section{Conclusion: Imagined Reader Communities}

An article of this length cannot exhaustively address the rich variety of details and nuance present in even the few examples that I have put forward; instead I have tried to succinctly demonstrate the benefit of using a certain method. That method looks for traces in manuscripts of an address made to someone who is not present yet, to someone whose presence is always awaited and perpetually postponed. It asks what it means for a text to be put out "into the world," to be made to address an imagined community made up of individuals separated from the composer or scribe in time and space, but with whom the possibility of communion is imagined, either in terms of shared literary and aesthetic tastes-as in the case of Diler Khan's copy of the Nal-Dāman — or in terms of a shared confessional identity-as in the case of the vanni manuscripts of religious poetry. The traces of this address and of those imagined communities can be found in the textual content as well as the material form of the manuscripts-though sometimes to become

28 On the concept of "sonic equality" in the context of religious movements of the period, see Christian Novetzke, The Quotidian Revolution: Vernacularization, Religion, and the Premodern Public Sphere in India (New York: Columbia University Press, 2016), 243-84.

29 Tyler Williams, "Sacred Sounds and Sacred Books: A History of Writing in Hindi," Ph.D. dissertation, Columbia University, 2014, pp. 264, 312-14. 
aware of them we must read "against the grain," taking utterances and signs ostensibly intended for the "original" individual user as oblique nods to future "readers," be they scribes, collectors, dealers, or devotees. As the examples here have hopefully made clear, the method must be attuned to genre, since some types of composition (like the Sufi romance) can be explored through analysis of a single type of textual artifact (the PersoArabic kitäb), while other types of composition (like the hymns and aphorisms of the bbakti saints) require the comparison of multiple types of textual artifacts (like the guțka notebook and the vān $\bar{\imath}$ vademecum). Ultimately, just as this method asks us to revise our approach to manuscripts of the period, it also requires us to rethink how we conceive of publics, or at least reader communities, for as Brian Stock and Mark Amsler have argued, reader communities are constituted not simply by people who "read" the same texts, but by people who share the social contexts and affective regimes associated with reading (Brian Street has made a similar argument for the concept of "literacy" itself). ${ }^{30}$ In the case of early modern north India, the social, performative, and affective fingerprints of these readers have been left all over the books they once loved.

\section{Acknowledgments}

I thank Arthur Dudney and Neeraja Poddar for organizing the panel on new approaches to manuscript studies at the 2016 European Conference on South Asian Studies in Warsaw, Poland, and for stewarding this issue of the journal to publication. I also thank Thibaut d'Hubert for his assistance in reading the colophon of the Nal Däman of Surdas, and for more generally sharing his knowledge of Persian and vernacular codicology and paleography; Qamar Adamjee at the Asian Art Museum of San Francisco for her invaluable thoughts on manuscripts of the Candāyan and for her assistance

30 Mark Amsler, Affective Literacies: Writing and Multilingualism in the Late Middle Ages (Turnhout: Brepols, 2012); Stock, The Implications of Literacy; Brian Street, Literacy in Theory and Practice (New York: Cambridge University Press, 1984). 
Williams: "Publishing" and Publics in a World Without Print

168 | Journal for Manuscript Studies

in viewing several manuscripts at the Museum; Kamal Sankhla and the Rajasthan Oriental Research Institute for their assistance in accessing materials in their collection; and the Chatrapati Shivaji Maharaj Vastu Sangrahalaya for their assistance in viewing the collection and for permission to use images of the Nal-Dāman and Cāndayan manuscripts. 